\title{
Past, Present and Future Perspectives of Sediment Compaction as a Driver of Relative Sea Level and Coastal Change
}

\author{
Matthew J. Brain ${ }^{1}$ \\ Published online: 14 June 2016 \\ (C) The Author(s) 2016. This article is published with open access at Springerlink.com
}

\begin{abstract}
Compaction describes a range of natural syn- and post-depositional processes that reduce the volume of sediments deposited in low-lying coastal areas, causing landlevel lowering and a distortion of stratigraphic sequences. Compaction affects our reconstructions and understanding of historic sea levels, influences how relative sea level changes in the future and can act as a catalyst for rapid, widespread changes in coastal geomorphology. Rates of compaction-induced relative sea-level rise vary across space and through time in response to a range of natural and anthropogenically accelerated processes and conditions. This paper provides a summary of our understanding of the causes and effects of compaction, considering findings from key palaeoenvironmental and stratigraphic studies, sea-level reconstructions and recent observational data. It then considers the implications of these findings for our ability to project compaction-induced relative sea-level and associated coastal changes into the future.
\end{abstract}

Keywords Compaction $\cdot$ Subsidence $\cdot$ Relative sea level . Coastal change

\section{Introduction}

Sea-level rise is arguably the most damaging and disruptive effect of climate change, with potentially widespread and

This article is part of the Topical Collection on Sea Level Projections

Matthew J. Brain

matthew.brain@durham.ac.uk

1 Department of Geography and Institute of Hazard Risk and Resilience, Durham University, South Road, Durham DH1 3LE, UK significant impacts on coastal populations, infrastructure, landforms and ecosystems [1-7]. To plan for and mitigate these adverse effects, assessing and projecting future sealevel rise as accurately as possible is a key scientific goal [8-13]. This requires a thorough understanding of the many drivers of sea-level change through space and time. The relationship between global climatic, hydrologic, cryospheric and oceanographic processes and sea level is increasingly well constrained, as are regional deviations in sea level from the global mean (see recent reviews by Clark et al. [12], Dutton et al. [14], Kemp et al. [15], Khan et al. [16], Kopp et al. [17], Leuliette [18] and references therein). Global to regional sea levels are modified by vertical land-level changes, driving relative sea-level changes (here, defined simply as changes in the difference in elevation between land level and sea level; see Shennan [19] for further information and critique of definitions of relative sea level (RSL)) at a particular location and time. Regional land-level changes can result from glacio-, sedimentary- and hydro-isostatic adjustment [20-23] and tectonic processes $[24,25]$. The focus of this review paper is on sediment compaction $[26,27 \cdot, 28,29]$ which, in addition to changes in sediment supply [30-33], can result in land-level changes at the local scale.

Compaction describes a range of natural syn- and postdepositional processes that reduce the volume of sediments deposited in low-lying coastal areas [34, 35], causing landlevel lowering (i.e. subsidence) [28]. This can occur as a result of stress- and time-dependent mechanical compression processes that reduce pore space and increase bulk density [36]. Compression processes include consolidation, which describes the expulsion of pore water from sediment interstices in response to burial by overburden sediments [37] or from self-weight [28] and creep, which describes ongoing viscous rearrangement of sediment particles [38••]. Predominantly organic sediments and peat deposits can also undergo florally 
and faunally mediated biochemical degradation, which can increase mass loss and can change the compressive strength of sediments [34, 39-42]. Compaction operates at various depths below ground level, and so a distinction is often made between near-surface (depths of $\leq 10 \mathrm{~m}$ or so below ground level) 'shallow subsidence' [43], typically occurring in de-

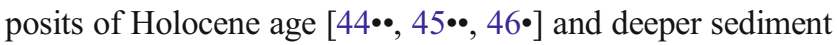
compaction in pre-Holocene sediments [9, 47-49]. Compaction can be accelerated by anthropogenic activity $[26,50,51]$, notably through land drainage [52-54] and exploitation of aquifers and hydrocarbon reserves $[55,56]$.

The contribution of sediment compaction to RSL rise is potentially highly significant at the local scale [38••, 44••], with some studies suggesting that compaction-induced subsidence can be equal to or greater than recent, current and projected rates of global sea-level rise [13, 57]. As such, there is a clear need to incorporate estimates of rates of compactiondriven land-level lowering into societally relevant and appropriate regional to local projections of RSL change to inform risk-management strategies [58, 59]. However, sediment compaction does not solely influence how RSL and coastlines may change in the future. It can also fundamentally affect the accuracy of reconstructions of historic sea level changes [35, 46•] which are crucial to our understanding of the controls on sea level and how these changed in the past; provide longer term context to current rates and patterns of sea-level change; and allow us to better constrain those that may occur in future $[8,14,15,60-63]$.

\section{Past}

\section{Stratigraphic and Palaeoenvironmental Studies}

Coastal stratigraphies and the palaeoenvironmental records contained within can be exploited to assess the magnitude and rate of compaction-induced subsidence over centennial to millennial timescales. In addition, coastal sedimentary archives can be used to obtain a broad understanding of the controls on compaction and some of the key effects on coastal landscapes.

Compaction has been widely observed to distort Holocene coastal stratigraphies $[34,64,65]$. Törnqvist et al. [44••], for example, presented a stratigraphic cross section obtained along a sediment coring transect extending approximately $5 \mathrm{~km}$ normal to the Bayou Lafourche, Paincourtville, Louisiana, USA (Fig. 1). They documented the $>2$-m differences in elevation of a near isochronous (c. $1400 \mathrm{cal} \mathrm{BP}$ ) peat layer which would have been effectively horizontal and uniform in elevation, covering extensive low-gradient coastal plains, at the time of formation. Subsequent deposition of thick (up to several metres), clastic overburden strata and differential compaction of underlying deposits distorted the peat stratum. Comparison of the in situ elevations of these intercalated samples with a reconstruction of the depositional altitude of the peat layer provided an estimate of the magnitude by which the peat layer has been lowered. This approach employs isochronous basal samples, which are situated directly on an incompressible surface and, hence, are unable to be lowered through compaction of underlying sediment. Törnqvist et al. [44••] noted post-depositional lowering (PDL) [46•] of the peat layer reached c. $6 \mathrm{~m}$ in some locations. In conjunction with the age of formation of the peat layer, Törnqvist et al. [44 •*] calculated averaged rates of compaction-induced subsidence of up to $5 \mathrm{~mm}$ year ${ }^{-1}$. They also suggested that compaction could create land level lowering rates of up to $10 \mathrm{~mm}$ year $^{-1}$ over shorter timescales, given the non-linear decline in the rate of compaction-induced lowering through time $[38 \cdot \bullet]$.

Long et al. [45.•] reported differences of up to c. $5.5 \mathrm{~m}$ in the elevation of the upper surface of a peat bed along a coring transect in the area surrounding Rye, East Sussex, Southeast England. They attributed these differences in elevation largely to the effects of differential sediment compaction. Palaeoenvironmental, chronological and sedimentological analysis of core sediments collected at West Winchelsea suggested that approximately $4.8 \mathrm{~m}$ of minerogenic sediment accumulated between c. 1186 and $1460 \mathrm{CE}$, resulting from landlevel lowering at an average rate of c. $18 \mathrm{~mm}_{\text {year }}{ }^{-1}$. Long et al. [45] attributed this to a geomorphic response to coastal barrier breaching, which increased water depths and tidal energy, and caused loading of the peat layer by infilling of newly available accommodation space by minerogenic sediment. Enhanced drainage and consolidation of the peat layer were likely to have been caused by headward erosion of tidal creeks in response to the increase in tidal prism and energy conditions. In turn, the peat experienced rapid compaction, causing local RSL rise. This caused further positive feedback, notably in terms of further deposition of dense minerogenic overburden sediments and consequent rapid changes to the coastal landscape.

\section{Relative Sea-Level Studies}

Compaction-induced stratigraphic distortion of coastal sediment successions has an important secondary effect on the proxy reconstructions of RSL recorded therein. The requisite sea-level index points (SLIs) provide an estimate of position of RSL both in space and in time [19]. Compilations of SLIs permit construction of age-altitude plots to assess changes in RSL through time. Compaction-induced PDL of SLIs obtained from coastal sediment deposits lowers SLIs from their depositional altitudes [28]. Where sediments record a rising RSL trend, PDL of SLIs results in an overestimation of the magnitude and rate of RSL rise [35, 66, 67] (Fig. 2). In contrast, if sediments record falling RSL, compaction-induced lowering 
Fig. 1 Stratigraphic cross-section normal to Bayou Lafourche near Paincourtville, LA, USA, displaying distortion of an initially horizontal peat surface of uniform elevation. The thickdashed horizontal line indicates the reconstructed initial elevation of the peat/swamp surface. The thick solid line indicates its position following compactioninduced lowering. Ages are in conventional radiocarbon years BP. $\mathrm{MSL}=$ contemporary mean sea level. For further details, view the original publication (ref. [44••]). Reprinted by permission from Macmillan Publishers Ltd: Nature Geoscience ([44••]; (C) 2008)

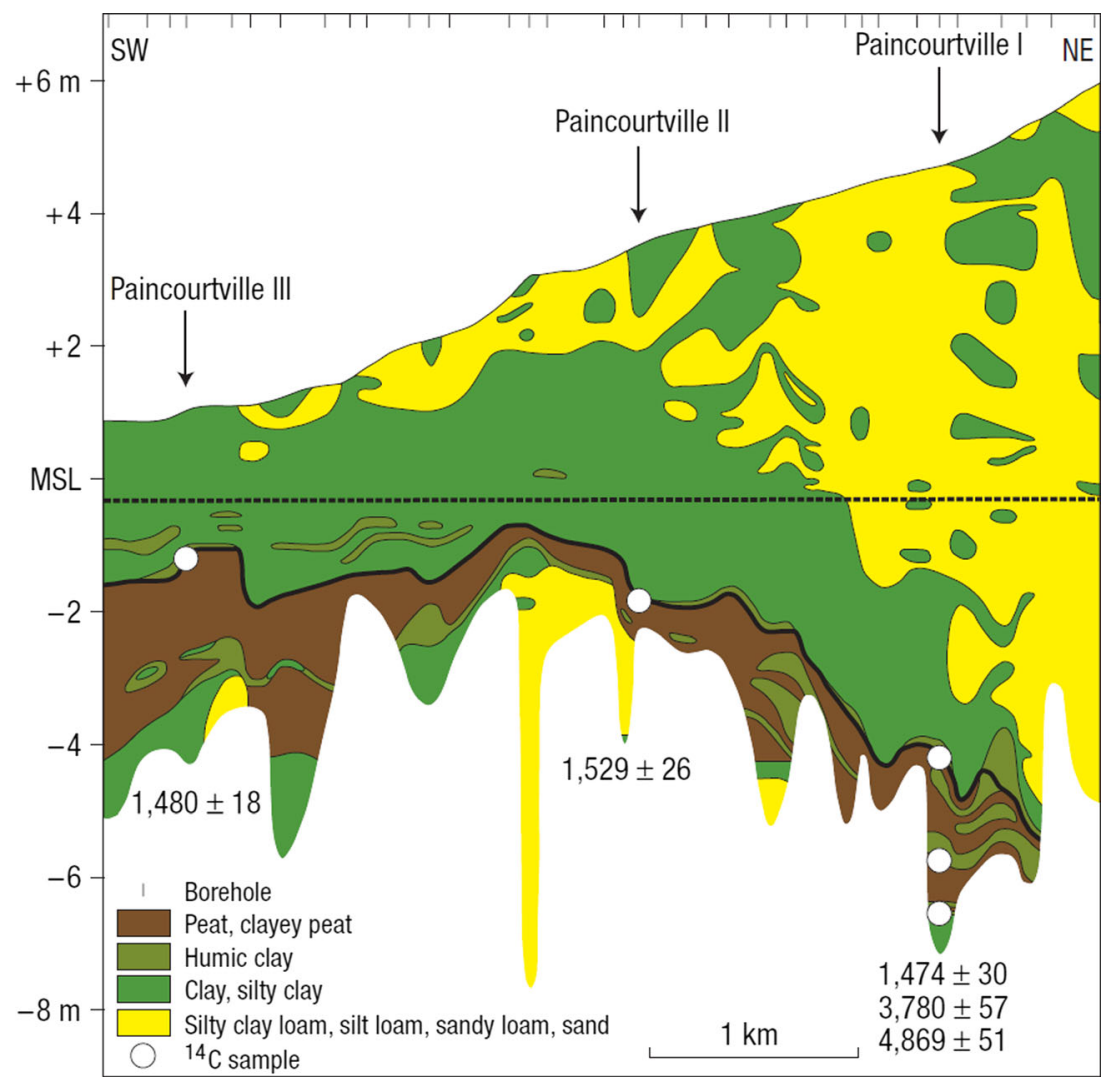

of SLIs causes an underestimate of the magnitude and rate of reconstructed RSL changes [35, 67] (Fig. 2).

Horton and Shennan [66] compiled a database of SLIs obtained from the Holocene coastal sediments of the eastern English coastline. They noted the considerable scatter in SLIs observed in regional sea-level curves of age against altitude. To assess the extent to which this scatter could be explained by sediment compaction and to estimate magnitudes and average rates thereof, Horton and Shennan [66] used a combination of basal SLIs and glacio-isostatic adjustment model results [68] to develop regionally specific compaction-free RSL records for the late Holocene. They noted that intercalated SLIs are located at elevations lower than their isochronous basal equivalents due to compaction-induced PDL. By considering the differences in elevation (i.e. the residuals) between compaction-prone (non-basal, intercalated) SLIs from and the modelled RSL curve, Horton and Shennan [66] calculated rates of calculated millennially averaged compaction-induced subsidence rates of $0.4 \pm 0.3 \mathrm{~mm}^{-1}$ yer $^{-1}$. They noted considerable spatial variation between regions, notably in relation to macro-scale coastal geomorphology. For example, in the larger Humber Estuary, Horton and Shennan [66] found compaction-induced PDL rates of $0.6 \pm 0.3 \mathrm{~mm}_{\text {year }}{ }^{-1}$.

To study regional differences in compaction-controlled RSL changes further, Horton and Shennan [66] plotted the elevation residuals against three key stratigraphic variables: (1) the thickness of the sediment overlying each SLI; (2) the thickness of sediment beneath each SLI and the underlying incompressible basement; and (3) the full thickness of the Holocene sediment in which the SLI is situated. The results suggest that the magnitude of compaction-induced lowering of SLIs is generally positively related to the thickness of overlying sediment and the overall thickness of the sediment column but negatively related to the depth to the incompressible pre-Holocene basement (Fig. 3). However, the relationship between the thickness of sediment beneath each SLI and the underlying incompressible basement is often more variable and not statistically significant [27•] (Fig. 3). Greater thicknesses of overburden create greater compressive stresses, reducing the thickness of underlying strata, though samples located near to the base of a stratigraphic column experience a lower magnitude of PDL as the potential for cumulative compression of underlying sediments is limited. Edwards [65], Törnqvist et al. [44••] and Horton et al. [27•] not only reported similar results but also noted that the magnitudes and rates of compaction processes are functions of the lithology of overburden sediments and, hence, the specific nature and sequence of the stratigraphy at any location. Indeed, the effects of compaction have been observed to be greater in stratigraphic successions where denser minerogenic sediments are deposited on top of lower density and greater compressibility

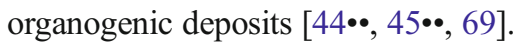

Horton and Shennan [66] determined that the inclusion of non-basal samples when calculating late Holocene rates of 
a - Sea level index point

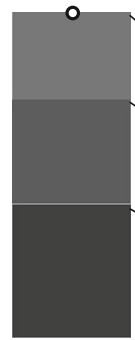

1. Sea level index point at altitude of deposition

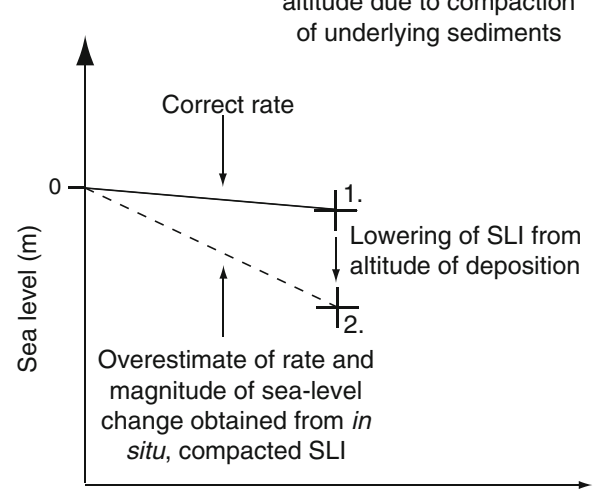

Years before present b

- Sea level index point

Deposition of overlying sediments

Compaction of underlying sediments
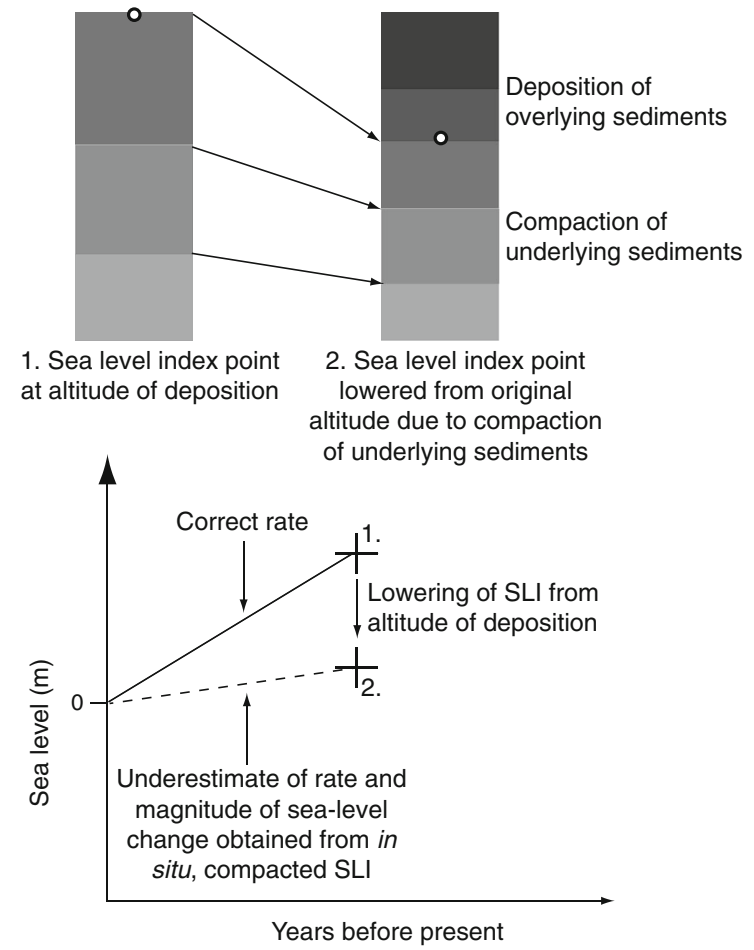

Years before present

† Sea level index point with age and altitude errors

Fig. 2 Schematic depiction of the effects of sediment compaction on sealevel index points within low-energy intertidal stratigraphic successions and the subsequent effects on age-altitude reconstructions of sea level in a 'transgressive' (deepening upwards) and b 'regressive' (shallowing upwards) successions. Scales in $\mathbf{a}$ and $\mathbf{b}$ are indicative and are not directly comparable. Source: Brain (ref. [35]; In: Shennan, I., Long, A.J. and Horton, B.P. (eds), Handbook of Sea-Level Research). (C) 2015 Wiley, Ltd., reproduced with permission
RSL rise causes an overestimation of up to $0.4 \mathrm{~mm}$ year $^{-1}$. This is important because late Holocene rates of RSL change can provide an indication of directions, rates and patterns of land-level changes resulting from glacio-isostatic adjustment
(GIA), assuming no or minimal meltwater inputs (see references in Engelhart et al. [70]). For this reason, regional compilations of SLIs favour the use of basal deposits to minimise the contribution of sediment compaction to reconstructed RSL
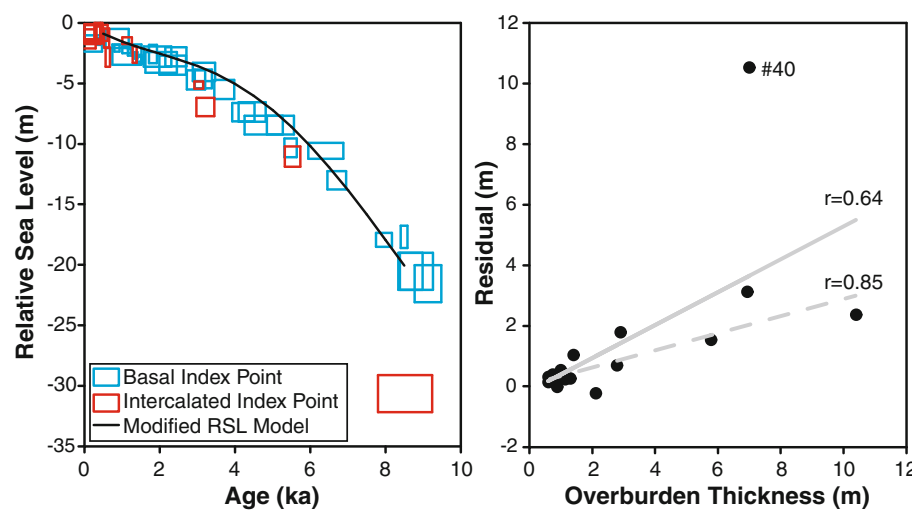

Fig. 3 From left to right: Holocene sea-level index points and modelled relative sea-level curve for New Jersey, USA. Sea-level index points are classed as either compaction-free basal samples or compaction-prone intercalated samples; overburden, depth to basement and total thickness of sediment versus residual for intercalated index points. 'Residual' is the difference between the fitted RSL curve and the centre point of each intercalated index point. In the second left graph (residual vs.
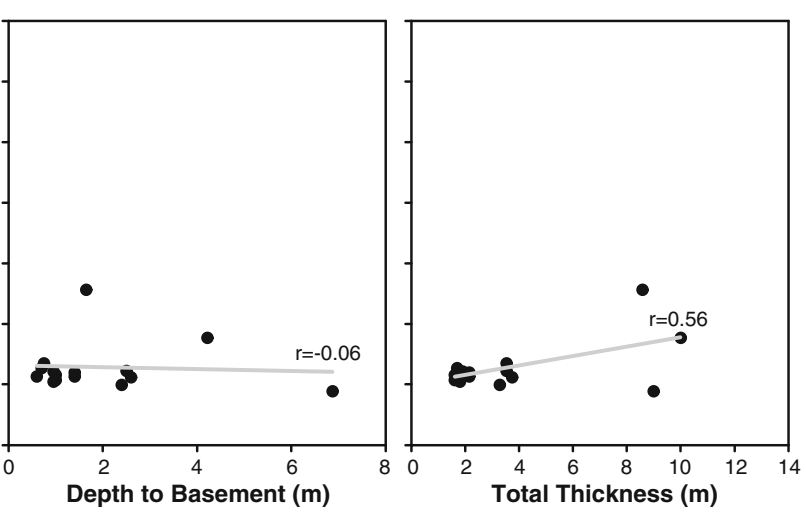

overburden thickness), index point \#40 formed at c. $8.5 \mathrm{ka}$ and is located $10 \mathrm{~m}$ below same age basal index points. The solid regression line (where $r=0.64$ ) includes index point \#40; the dashed regression line (where $r=0.85$ ) excludes it. This removal is justified by Horton et al. $[27 \cdot]$ on the basis of significant anthropogenic disturbance at the site. Source: Horton et al. [27•]. (C) 2013 Wiley, Ltd., reproduced with permission 
change and in determining background rates of GIAcontrolled RSL [70-72]. Similarly, the use of compactionfree basal SLIs is preferable when reconstructing RSL over multi-decadal to centennial timescales, where greater temporal resolution is required to permit comparison with climatic, oceanographic and cryospheric datasets [8, 61, 73]. However, basal peats are not ubiquitous through time and space [71] and very few studies have used them to assess sub-millennial variability in RSL $[60,74]$.

Where basal peats are not present or suitable at a particular location, geotechnical modelling provides a means of correcting post-depositionally lowered SLIs for the effects of compaction $[37,39,75,76]$. This approach is based on theories and models developed in geotechnical engineering and soil mechanics that have subsequently been refined to suit the specific geotechnical properties of intertidal sediments that result from the unique lithologies and hydrogeological and early-stage diagenetic conditions encountered in intertidal settings $[36,46 \bullet]$. Geotechnical modelling requires considerable empirical input to quantify the strength properties of the contemporary and core sediments of interest but permits samples at all depths within a single core of sediment to be 'decompacted' and returned to their depositional altitude, even in the absence of basal SLIs [35]. Such models are able to accurately reproduce the depth-specific values of bulk density measured in sediment cores $[35,67 \cdot \bullet]$ and replicate the broad patterns of compaction effects seen in stratigraphic field investigations noted above, such as greater contributions of compaction to PDL in deeper, transgressive sequences [46 ${ }^{\bullet}$ ].

Recently, geotechnical modelling studies have better constrained the influence of compaction on reconstructed RSL over the last 200 or so year, during which global sealevel rise accelerated in response to increases in global temperature $[8,77]$. Reconstructions of absolute sea level from salt-marsh deposits in the northern $[60,61,73,74,78-83]$ and southern $[63,84]$ hemispheres have revealed an inflection that varies spatially in terms of the timing, abruptness and magnitude of acceleration [77]. Brain et al. [46•] numerically demonstrated that compaction can contribute up to $0.4 \mathrm{~mm}_{\text {year }}{ }^{-1}$ of local sea-level rise to reconstructions of RSL obtained from salt-marsh sediments in successions $\leq 3$-m thick. As such, they demonstrated that the order-of-magnitude increases in the rate of sea level recorded in salt-marsh sediments resulted from increases in absolute sea level, and cannot be explained solely as an increase in local RSL resulting from sediment compaction [85]. However, spatial differences in compaction-driven PDL are of the same order of magnitude and range as those resulting from other processes that control RSL [10, 86-89]. Therefore, if not corrected for, compaction could influence our interpretations of the processes causing spatial variability in RSL. To this end, further geotechnical modelling is required at a greater range of sites to ascertain spatial variability in compaction-induced subsidence.
Brain et al. [67••] applied the geotechnical modelling approach to a core of salt-marsh sediment from North Carolina, USA, to determine the degree to which it has been affected by compaction-induced PDL. The North Carolina sea-level record has been used as a pseudo-global sea-level reconstruction and has been used to calibrate semi-empirical models of climate-related sea-level variability and project future global sea-level changes in response to temperature changes [61]. If the observed historical relationship between global temperature and sea level is incorrect as a result of PDL effects in the North Carolina record, future projections of climatecontrolled sea level would overestimate the rate and magnitude of future sea-level rise. Brain et al. [67•.0] determined that the key features of the North Carolina sea-level record were not an artefact of sediment compaction, though minor PDL of up to $2.5 \mathrm{~cm}$ was observed in the core (Fig. 4). This finding improves confidence in the relationship between modelled global sea level and temperature and, hence, future projections of sea-level rise $[10,11]$.

\section{Present}

Present-day observations of rates of compaction-induced subsidence in coastal environments have been made at a variety of scales [55, 90•, 91, 92, 93]. Cahoon et al. [43], for example, reported point measurements of subsidence resulting from compaction of near-surface salt-marsh stratigraphies in Louisiana, Florida and North Carolina, Southeastern, USA. Over a 2-year monitoring period, Cahoon et al. [43] recorded shallow subsidence of 0.45 to $4.50 \mathrm{~cm}$, equivalent to annually averaged rates of 2.3 to $22.5 \mathrm{~mm}_{\text {year }}{ }^{-1}$. Anthropogenic activity can accelerate compaction and associated subsidence significantly, as was documented during the drainage of Whittlesey Mere which, prior to drainage, was a 400 500 ha, c. 1-m deep lake [54] in the East Anglian Fenlands, UK. Drainage of the Mere and groundwater table lowering caused consolidation and wastage of an extensive peat layer, resulting in subsidence of $3.91 \mathrm{~m}$ over c. 128 years $(1850$ $1978 \mathrm{CE}$ ), equivalent to an average rate of $30.5 \mathrm{~mm}$ year $^{-1}$ [54]. Maximum subsidence rates during the early stages of drainage were observed to reach $220 \mathrm{~mm}_{\text {year }}{ }^{-1}$ [54], demonstrating the potential significance of compaction processes in driving RSL changes.

Point estimates cannot, however, provide sufficient spatial coverage to appropriately constrain variability in subsidenceinduced compaction over coastal landscapes, particularly the widespread subsidence observed over large river delta systems [51]. To this end, remote sensing techniques, notably Interferometric Synthetic Aperture Radar (InSAR), can be used to accurately and precisely (i.e. with millimetre scale resolution) measure vertical changes in land level through 


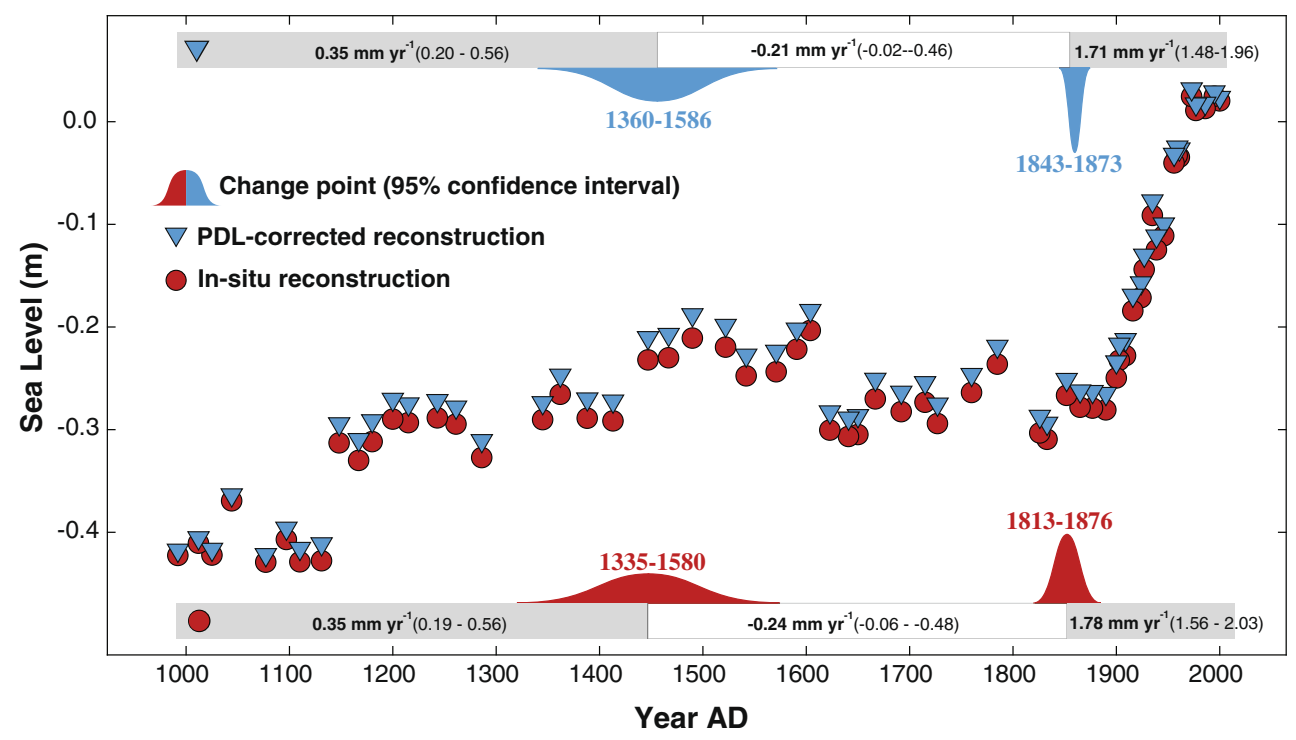

Fig. 4 Reconstructed sea-level changes at Tump Point, NC, USA following correction for land-level change resulting from glacioisostatic adjustment $\left(0.9 \mathrm{~mm} \mathrm{year}^{-1}\right)$. A statistical model identified persistent sea-level trends for the in situ (red circles) and decompacted (blue triangles) reconstructions. For clarity, reconstructions are presented as estimate midpoints without vertical or temporal uncertainties (see ref. [61] for further details of errors). Reprinted from Brain et al. [67••]. (C) 2014, with permission from University of Washington/Elsevier Inc time, particularly where fixed location ground reflectors ('permanent scatterers') can be exploited [94-97].

Higgins et al. [98••] used InSAR to determine rates of compaction-induced subsidence in the Ganges-Brahmaputra delta, Bangladesh, noting average annual rates of up to $18 \mathrm{~mm} \mathrm{year}^{-1}$ over a c. 4-year period $(2007-2011 \mathrm{CE})$. The InSAR results demonstrated good agreement with direct point measurements of subsidence but provided a considerably more detailed assessment of spatial patterns of subsidence and the variability therein (Fig. 5), as also noted in many studies employing a range of techniques [92, 99, 100]. In turn, this permitted Higgins et al. [98••] to consider the causes of subsidence. Comparison with regional geology maps revealed a strong sub-surface lithological control on subsidence rates, the lowest of which were observed in areas where stiffer Pleistocene clays outcropped [98••]. In contrast, the highest rates of subsidence were noted where surface deposits were composed of softer organic Holocene muds. Similar high rates $\left(\leq 15 \mathrm{~mm}\right.$ year $\left.^{-1}\right)$ of subsidence in Holocene sediments (depths of 30-40 m below ground level) have been reported in the Po Delta, Northeastern Italy by Teatini et al. [101] on the basis of an 8-year (1992-2000 CE) interferometric monitoring dataset.

InSAR has also been used to assess the spatial pattern of rates of subsidence associated with consolidation of porous strata as a result of groundwater abstraction over large (of the order $10^{3} \mathrm{~km}^{2}$ ) areas. Erban et al. [102], for example, reported rates of c. $10-40 \mathrm{~mm}$ year $^{-1}$ in the Mekong Delta, Vietnam, between 2006 and 2010 CE. These rates correlated well with calculations of compaction-induced subsidence based on changes in hydraulic head measured in groundwater monitoring wells, demonstrating the utility of predictive models where the compaction process is sufficiently isolated and understood (see also [103-106]). However, assigning a cause for observed subsidence is not always straightforward and often requires careful critique and comparison of monitoring techniques, datasets and modelling approaches $[49,55$, 91].

\section{Future}

Our understanding of compaction processes and effects has contributed greatly to our ability to constrain the many controls on RSL, such that local to regional scale projections thereof grow increasingly robust. For example, use of basal peat-derived RSL data and geotechnical modelling of compaction-induced PDL has improved the accuracy of long-term estimates of GIA $[66,71,86]$ and improved confidence in our projections of climate-related global sea-level variability $[46 \bullet, 67 \bullet \bullet]$.

Compaction is, and will continue to be, a significant driver of RSL rise in some locations in future [26, 57]. Global mean sea level between 1901 and 1990 rose at a rate of $1.2 \pm$ $0.2 \mathrm{~mm}$ year $^{-1}$, as determined from probabilistic (re-)analysis of tide gauge records and inputs from physics-based numerical models [107]. Examination of satellite altimetry records (namely those obtained by the TOPEX/Poseidon and Jason missions) indicated that the average rate of global sea-level rise between 1993 and 2009 was $3.4 \pm 0.4 \mathrm{~mm} \mathrm{year}^{-1}$ 
Fig. 5 Rates of subsidence recorded for the GangesBrahmaputra-Meghna delta and surrounding areas, demonstrating the resolution of coverage provided by InSAR methods (data are from ref. [98••]) relative to point-based estimates. Source: Brown and Nicholls [90•], 10. 1016/j.scitotenv.2015.04.124, reproduced under Creative Commons Attribution-

NonCommercial-NoDerivatives (CC BY NC ND) 4.0

International Public License http://creativecommons.org/ licenses/by-nc-nd/4.0/ and with permission from S. Brown. See original publications for discussion of the sources and accuracy of individual data points

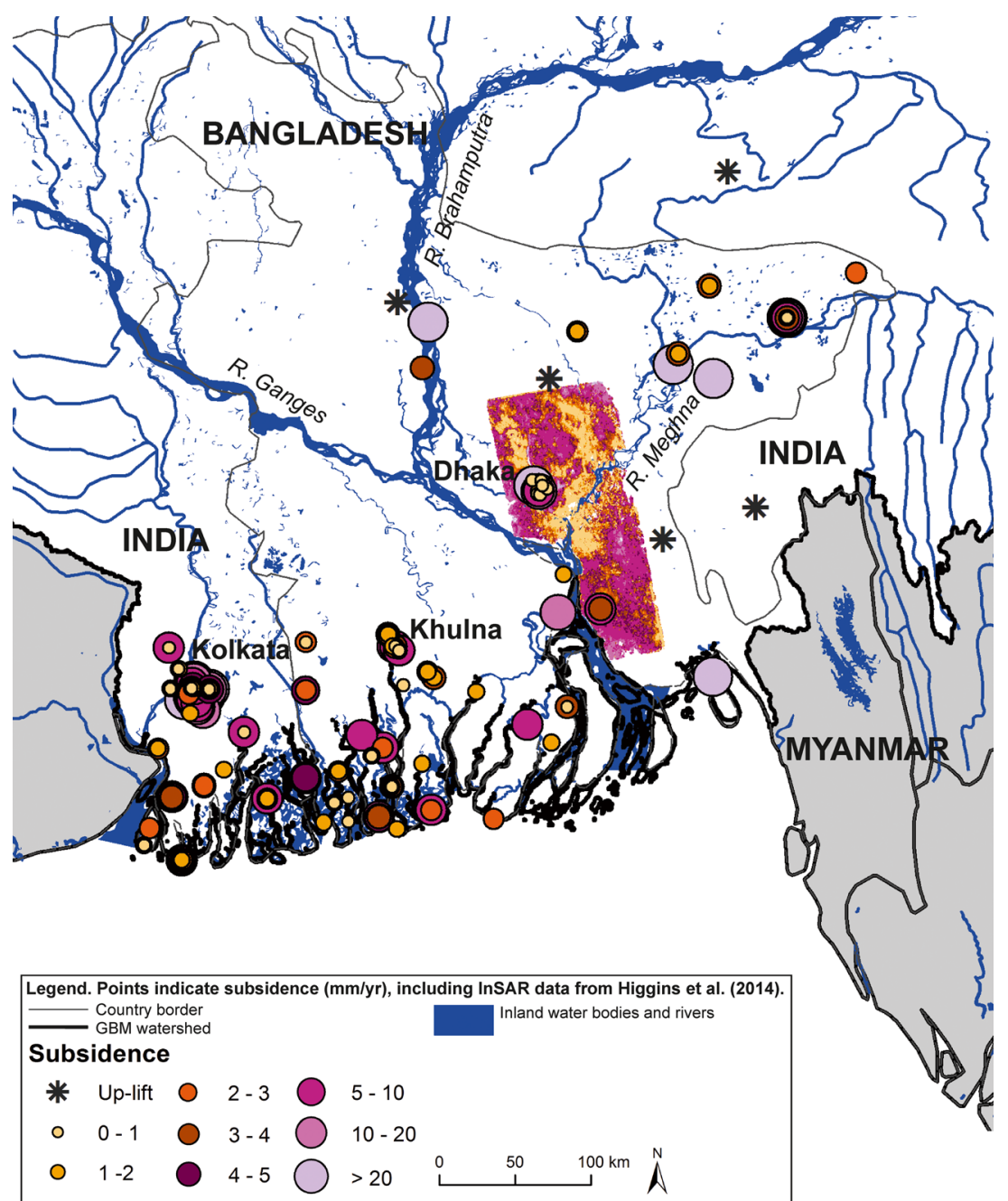

[108]. Future accelerations are deemed to be highly likely, primarily in response to thermal expansion of ocean waters and enhanced melting of ice caps and glaciers [13]. The highest emissions and temperature rise scenario considered by the Intergovernmental Panel on Climate Change (IPCC) Fifth Assessment Report (AR5) project rates of rise of between 8 and $16 \mathrm{~mm}$ year $^{-1}$ (Representative Concentration Pathway (RCP) 8.5) during the period 2081 to 2100 [13]. In some locations, reported rates of compaction-induced subsidence can equal or even greatly exceed the highest rates of projected global sea-level rise.

Projecting rates of compaction-induced subsidence into the future is not a trivial task. The stratigraphic record provides considerable insight into the sub-surface controls on compaction and adds longer term context to contemporary observations of subsidence rates. However, reported rates of compaction-induced subsidence vary considerably in terms of the measurement method employed; causal mechanism; spatial location, coverage and resolution; duration of the observation period; and in terms of the quality and accuracy of the data reported [90]. Extrapolation of observed rates may be appropriate over short (sub-decadal) timescales, but subsidence rates can change extremely rapidly (i.e. over annual to monthly timescales) in some circumstances, particularly where anthropogenic activities provide the causal mechanism [92, 97] or where geomorphic thresholds are exceeded [45••].

Put simply, compaction operates at the local scale over a variety of timescales; as such, assessment and projection of compaction-induced land-level lowering require local scale, site-specific studies to identify the causes of compaction and the depths at which they operate. Encouragingly, as outlined here, identifying such controls on compaction can be achieved through a combination of contemporary observations and stratigraphic studies. In turn, such processes can then be modelled where our understanding of process permits, allowing increasingly robust projections of compaction-induced subsidence. Recent modelling work [38••, 76] has demonstrated how accurate and robust assessment of compaction can 
be achieved with an appropriate geotechnical model, permitting local to regional scale assessment of land-level lowering in complex stratigraphies and unique lithologies over short- to medium-term timescales.

It is also critical that future assessment of compactioninduced RSL rise in coastal environments does not focus solely on changes in elevation. Compaction is one of many geomorphic processes operating in coastal environments, and is intricately linked to marine, fluvio-estuarine and coastal sedimentary processes $[26,32,39,45 \bullet \cdot$. Hence, the potential for compaction to cause rapid and widespread coastal change should not be neglected; incorporating the effects of compaction into conceptual models and numerical simulations of coastal wetland behaviour is an important ongoing consideration $[5,39,109]$.

\section{Conclusions}

My key conclusions are as follows:

1. Sediment compaction is an important process in coastal stratigraphic successions. Compaction reduces the volume of coastal sediment deposits. The resultant land-level lowering creates a local relative sea-level rise.

2. Stratigraphic studies and observational data have revealed that rates of compaction are variable both spatially and temporally but can be greater than current and projected increases in absolute sea level.

3. Compaction influences our interpretations of reconstructions of relative sea-level change obtained from compactionprone coastal stratigraphies. Without correction, this affects the accuracy of estimates of long-term rates and spatial patterns of glacio-isostatic adjustment and can affect our understanding of the sensitivity of global sea level to past and projected temperature changes.

4. Our ability to project rates of compaction-induced coastal subsidence into the future depends on accurate assessment of causal compaction processes and the spatial and temporal timescales over which they operate and subsequent robust numerical modelling of resultant land-level changes and subsequent changes in coastal geomorphology.

Acknowledgments This paper is a contribution to the PaleoConstraints on Sea Level Rise 2 (PALSEA2) working group and IGCP Project 639 'Sea Level Change from Minutes to Millennia'. MB thanks two anonymous reviewers for their helpful comments and Sally Brown, Stephanie Higgins, Ben Horton and Tor Törnqvist for permitting the use of their figures and data in this paper.

\section{Compliance with Ethical Standards}

Conflict of Interest The corresponding author states that there is no conflict of interest.
Open Access This article is distributed under the terms of the Creative Commons Attribution 4.0 International License (http:// creativecommons.org/licenses/by/4.0/), which permits unrestricted use, distribution, and reproduction in any medium, provided you give appropriate credit to the original author(s) and the source, provide a link to the Creative Commons license, and indicate if changes were made.

\section{References}

Papers of particular interest, published recently, have been highlighted as:

- Of importance

•. Of major importance

1. Nicholls RJ, Cazenave A. Sea-level rise and its impact on coastal zones. Science. 2010;328(5985):1517-20.

2. Lentz EE, Thieler ER, Plant NG, Stippa SR, Horton RM, Gesch DB. Evaluation of dynamic coastal response to sea-level rise modifies inundation likelihood. Nat Clim Chang. 2016; advance online publication.

3. Hauer ME, Evans JM, Mishra DR. Millions projected to be at risk from sea-level rise in the continental United States. Nat Clim Change. 2016; advance online publication.

4. Kemp AC, Horton BP. Contribution of relative sea-level rise to historical hurricane flooding in New York City. J Quat Sci. 2013;28(6):537-41.

5. Kirwan ML, Guntenspergen GR, D’Alpaos A, Morris JT, Mudd SM, Temmerman S. Limits on the adaptability of coastal marshes to rising sea level. Geophys Res Lett. 2010;37(23).

6. Prime T, Brown JM, Plater AJ. Physical and economic impacts of sea-level rise and low probability flooding events on coastal communities. PLoS ONE. 2015;10(2):e0117030.

7. Nicholls RJ, Hoozemans FMJ, Marchand M. Increasing flood risk and wetland losses due to global sea-level rise: regional and global analyses. Glob Environ Chang. 1999;9(Supplement 1):S69-87.

8. Kopp RE, Kemp AC, Bittermann K, Horton BP, Donnelly JP, Gehrels WR, et al. Temperature-driven global sea-level variability in the Common Era. Proc Natl Acad Sci. 2016;113(11):E1434-41.

9. Miller KG, Kopp RE, Horton BP, Browning JV, Kemp AC. A geological perspective on sea-level rise and its impacts along the U.S. mid-Atlantic coast. Earth's future. 2013.

10. Kopp RE, Horton BP, Kemp AC, Tebaldi C. Past and future sealevel rise along the coast of North Carolina. USA Clim Chang. 2015;132(4):693-707.

11. Gehrels R, Horton BP, Kemp AC, Sivan D. Two millennia of sealevel data: the key to predicting change. EOS Trans Am Geophys Union. 2011;92(35):289-91.

12. Clark PU, Shakun JD, Marcott SA, Mix AC, Eby M, Kulp S, et al. Consequences of twenty-first-century policy for multi-millennial climate and sea-level change. Nat Clim Chang. 2016;6(4):360-9.

13. Church JA, Clark PU, Cazenave A, Gregory JM, Jevrejeva S, Levermann A, et al. Sea level change. In: Stocker TF, Qin D, Plattner G-K, Tignor M, Allen SK, Boschung J, Nauels A, Xia Y, Bex V, Midgley PM, editors. Climate change 2013: the physical science basis contribution of Working Group I to the Fifth Assessment Report of the Intergovernmental Panel on Climate Change. Cambridge: Cambridge University Press; 2013.

14. Dutton A, Carlson AE, Long AJ, Milne GA, Clark PU, DeConto $\mathrm{R}$, et al. Sea-level rise due to polar ice-sheet mass loss during past warm periods. Science. 2015;349(6244).

15. Kemp AC, Dutton A, Raymo ME. Paleo constraints on future sealevel rise. Curr Clim Chang Rep. 2015;1(3):205-15. 
16. Khan NS, Ashe E, Shaw TA, Vacchi M, Walker J, Peltier WR, et al. Holocene relative sea-level changes from near-, intermediate-, and far-field locations. Curr Clim Chang Rep. 2015;1(4):247-62.

17. Kopp RE, Hay CC, Little CM, Mitrovica JX. Geographic variability of sea-level change. Curr Clim Chang Rep. 2015;1(3):192204

18. Leuliette EW. The balancing of the sea-level budget. Curr Clim Chang Rep. 2015;1(3):185-91.

19. Shennan I. Handbook of sea-level research: framing research questions. In: Shennan I, Long AJ, Horton BP, editors. Handbook of sea-level research. Wiley, Ltd.; 2015. p. 3-25.

20. Wolstencroft M, Shen Z, Törnqvist TE, Milne GA, Kulp M. Understanding subsidence in the Mississippi Delta region due to sediment, ice, and ocean loading: insights from geophysical modeling. J Geophys Res Solid Earth. 2014;119(4):3838-56.

21. Milne GA, Mitrovica JX, Davis JL. Near-field hydro-isostasy: the implementation of a revised sea-level equation. Geophys J Int. 1999;139(2):464-82

22. Tamisiea ME. Ongoing glacial isostatic contributions to observations of sea level change. Geophys J Int. 2011;186(3):1036-44.

23. Ivins ER, Dokka RK, Blom RG. Post-glacial sediment load and subsidence in coastal Louisiana. Geophys Res Lett. 2007;34(16).

24. Atwater BF. Evidence for great earthquakes along the outer coast of Washington State. Science. 1987;236:942-4.

25. Rowley DB, Forte AM, Moucha R, Mitrovica JX, Simmons NA, Grand SP. Dynamic topography change of the Eastern United States since 3 million years ago. Science. 2013;340(6140):1560 3.

26. Syvitski JPM, Kettner AJ, Overeem I, Hutton EWH, Hannon MT, Brakenridge GR, et al. Sinking deltas due to human activities. Nat Geosci. 2009;2(10):681-6.

27. Horton B, Engelhart SE, Hill DF, Kemp AC, Nikitina DL, Miller $\mathrm{KG}$, et al. Influence of tidal-range change and sediment compaction on Holocene relative sea-level change in New Jersey. USA J Quat Sci. 2013;28(4):403-11. Uses basal peats to assess the contribution of compaction to sea-level changes over the Holocene.

28. Kaye CA, Barghoorn ES. Late quaternary sea-level change and crustal rise at Boston, Massachusetts, with notes on the autocompaction of peat. Geol Soc Am Bull. 1964;75(2):63-80.

29. Bloom AL. Peat accumulation and compaction in Connecticut coastal marsh. J Sediment Res. 1964;34(3):599-603.

30. Long AJ, Scaife RG, Edwards RJ. Pine pollen in intertidal sediments from Poole Harbour, UK; implications for late-Holocene sediment accretion rates and sea-level rise. Quat Int. 1999;55(1): 3-16.

31. Mellett CL, Hodgson DM, Lang A, Mauz B, Selby I, Plater AJ. Preservation of a drowned gravel barrier complex: a landscape evolution study from the north-eastern English Channel. Mar Geol. 2012;315-318:115-31.

32. Syvitski JPM, Kettner AJ, Correggiari A, Nelson BW. Distributary channels and their impact on sediment dispersal. Mar Geol. 2005;222-223:75-94.

33. Spencer CD, Plater AJ, Long AJ. Rapid coastal change during the mid- to late Holocene: the record of barrier estuary sedimentation in the Romney Marsh region, southeast England. The Holocene. 1998;8(2):143-63.

34. Allen JRL. Morphodynamics of Holocene salt marshes: a review sketch from the Atlantic and Southern North Sea coasts of Europe. Quat Sci Rev. 2000;19(12):1155-231.

35. Brain MJ. Compaction. Handbook of sea-level research: Wiley, Ltd; 2015. p. 452-69.

36. Brain MJ, Long AJ, Petley DN, Horton BP, Allison RJ. Compression behaviour of minerogenic low energy intertidal sediments. Sediment Geol. 2011;233(1-4):28-41.
37. Pizzuto JE, Schwendt AE. Mathematical modeling of autocompaction of a Holocene transgressive valley-fill deposit, Wolfe Glade. Delaware Geol. 1997;25(1):57-60.

38.•v van Asselen S. The contribution of peat compaction to total basin subsidence: implications for the provision of accommodation space in organic-rich deltas. Basin Res. 2011;23(2):239-55. Uses a numerical model to calculate rates of, and controls on, compaction in deltas.

39. van Asselen S, Stouthamer E, van Asch TWJ. Effects of peat compaction on delta evolution: a review on processes, responses, measuring and modeling. Earth Sci Rev. 2009;92(1-2):35-51.

40. Lillebø AI, Flindt MR, Pardal M, Marques JC. The effect of macrofauna, meiofauna and microfauna on the degradation of Spartina maritima detritus from a salt marsh area. Acta Oecol. 1999;20(4): 249-58.

41. Hobbs NB. Mire morphology and the properties and behaviour of some British and foreign peats. Q J Eng Geol Hydrogeol. 1986;19(1):7-80.

42. Gambolati G, Putti M, Teatini P, Camporese M, Ferraris S, Stori GG, et al. Peat land oxidation enhances subsidence in the Venice watershed. Eos, Trans Am Geophys Union. 2005;86(23):217-20.

43. Cahoon DR, Reed DJ, Day Jr JW. Estimating shallow subsidence in microtidal salt marshes of the southeastern United States: Kaye and Barghoorn revisited. Mar Geol. 1995;128(1-2):1-9.

44.• Törnqvist TE, Wallace DJ, Storms JEA, Wallinga J, van Dam RL, Blaauw M, et al. Mississippi Delta subsidence primarily caused by compaction of Holocene strata. Nat Geosci. 2008;1(3):173-6. Key stratigraphic study that calculates rates of compactioninduced subsidence over centennial to millennial timescales.

45.• Long AJ, Waller MP, Stupples P. Driving mechanisms of coastal change: peat compaction and the destruction of late Holocene coastal wetlands. Mar Geol. 2006;225(1-4):63-84. Demonstrates the significance of compaction as a key geomorphic process in intertidal wetlands.

46. Brain MJ, Long AJ, Woodroffe SA, Petley DN, Milledge DG, Parnell AC. Modelling the effects of sediment compaction on salt marsh reconstructions of recent sea-level rise. Earth Planet Sci Lett. 2012;345-348:180-93. Develops a process-based compaction model to 'decompact' stratigraphic successions.

47. Kominz MA, Browning JV, Miller KG, Sugarman PJ, Mizintseva S, Scotese CR. Late Cretaceous to Miocene sea-level estimates from the New Jersey and Delaware coastal plain coreholes: an error analysis. Basin Res. 2008;20(2):211-26.

48. Van Sickel WA, Kominz MA, Miller KG, Browning JV. Late Cretaceous and Cenozoic sea-level estimates: backstripping analysis of borehole data, onshore New Jersey. Basin Res. 2004;16(4): 451-65.

49. Karegar MA, Dixon TH, Engelhart SE. Subsidence along the Atlantic Coast of North America: insights from GPS and late Holocene relative sea level data. Geophys Res Lett. 2016;43(7): 3126-33.

50. Ericson JP, Vörösmarty CJ, Dingman SL, Ward LG, Meybeck M. Effective sea-level rise and deltas: causes of change and human dimension implications. Global Planet Chang. 2006;50(1-2):6382 .

51. Higgins SA. Review: advances in delta-subsidence research using satellite methods. Hydrogeol J. 2015;1-14.

52. Vincent RE, Burdick DM, Dionne M. Ditching and ditchplugging in New England salt marshes: effects on hydrology, elevation, and soil characteristics. Estuar Coasts. 2013;36(3): 610-25.

53. Ewing JM, Vepraskas MJ. Estimating primary and secondary subsidence in an organic soil 15, 20, and 30 years after drainage. Wetlands. 2006;26(1):119-30. 
54. Hutchinson JN. The record of peat wastage in the East Anglian Fenlands at Holme Post, 1848-1978 A.D. J Ecol. 1980;68(1): 229-49.

55. Meckel TA. An attempt to reconcile subsidence rates determined from various techniques in southern Louisiana. Quat Sci Rev. 2008;27(15-16):1517-22.

56. Chan AW, Zoback MD. The role of hydrocarbon production on land subsidence and fault reactivation in the Louisiana Coastal Zone. J Coast Res. 2007;771-86.

57. Syvitski JPM. Deltas at risk. Sustain Sci. 2008;3(1):23-32

58. Hinkel J, Jaeger C, Nicholls RJ, Lowe J, Renn O, Peijun S. Sealevel rise scenarios and coastal risk management. Nat Clim Chang. 2015;5(3):188-90.

59. Gehrels WR, Dawson DA, Shaw J, Marshall WA. Using Holocene relative sea-level data to inform future sea-level predictions: an example from southwest England. Glob Planet Chang. 2011;78(3-4):116-26.

60. Kemp AC, Hawkes AD, Donnelly JP, Vane CH, Horton BP, Hill $\mathrm{TD}$, et al. Relative sea-level change in Connecticut (USA) during the last 2200 yrs. Earth Planet Sci Lett. 2015;428:217-29.

61. Kemp AC, Horton B, Donnelly JP, Mann ME, Vermeer M, Rahmstorf S. Climate related sea-level variations over the past two millennia. Proc Natl Acad Sci. 2011;108(27):11017-22.

62. Bittermann K, Rahmstorf S, Perrette M, Vermeer M. Predictability of twentieth century sea-level rise from past data. Environ Res Lett. 2013;8(1):014013.

63. Gehrels WR, Callard SL, Moss PT, Marshall WA, Blaauw M, Hunter J, et al. Nineteenth and twentieth century sea-level changes in Tasmania and New Zealand. Earth Planet Sci Lett. 2012;315316:94-102.

64. Jelgersma S. Holocene sea level changes in the Netherlands. Maastricht: Van Aelst; 1961. p. 101

65. Edwards RJ. Mid-to late-Holocene relative sea-level change in southwest Britain and the influence of sediment compaction. The Holocene. 2006;16(4):575-87.

66. Horton BP, Shennan I. Compaction of Holocene strata and the implications for relative sea-level change on the east coast of England. Geology. 2009;37(12):1083-6.

67.•• Brain MJ, Kemp AC, Horton BP, Culver SJ, Parnell AC, Cahill N. Quantifying the contribution of sediment compaction to late Holocene salt-marsh sea-level reconstructions, North Carolina. USA Q Res. 2015;83(1):41-51. Uses geotechnical modelling to assess the contribution of compaction to late Holocene sea level reconstructions.

68. Lambeck K, Johnston P. Land subsidence and sea-level change: contributions from the melting of the last great ice sheets and the isostatic adjustment of the Earth. In: Barends FBJ, editor. Land subsidence. Rotterdam: Balkema; 1995. p. 3-18.

69. Allen JRL. Geological impacts on coastal wetland landscapes: some general effects of sediment autocompaction in the Holocene of northwest Europe. The Holocene. 1999;9(1):1-12.

70. Engelhart SE, Horton BP, Douglas BC, Peltier WR, Tornqvist TE. Spatial variability of late Holocene and 20th century sea-level rise along the Atlantic coast of the United States. Geology. 2009;37(12):1115-8.

71. Shennan I, Horton B. Holocene land- and sea-level changes in Great Britain. J Quat Sci. 2002;17(5-6):511-26.

72. Engelhart SE, Horton BP. Holocene sea level database for the Atlantic coast of the United States. Quat Sci Rev. 2012;54:12-25.

73. Saher MH, Gehrels WR, Barlow NLM, Long AJ, Haigh ID, Blaauw M. Sea-level changes in Iceland and the influence of the North Atlantic Oscillation during the last half millennium. Quat Sci Rev. 2015;108:23-36.

74. Donnelly JP, Cleary P, Newby P, Ettinger R. Coupling instrumental and geological records of sea-level change: evidence from southern New England of an increase in the rate of sea-level rise in the late 19th century. Geophys Res Lett. 2004;31(5):L05203.

75. Paul MA, Barras BF. A geotechnical correction for postdepositional sediment compression: examples from the Forth valley. Scotland J Quat Sci. 1998;13(2):171-6.

76. van Asselen S, Karssenberg D, Stouthamer E. Contribution of peat compaction to relative sea-level rise within Holocene deltas. Geophys Res Lett. 2011;38(24).

77. Gehrels WR, Woodworth PL. When did modern rates of sea-level rise start? Global Planet Chang. 2013;100:263-77.

78. Kemp AC, Bernhardt CE, Horton BP, Kopp RE, Vane CH, Peltier WR, et al. Late Holocene sea- and land-level change on the U.S. southeastern Atlantic coast. Mar Geol. 2014;357:90-100.

79. Kemp AC, Horton BP, Culver SJ, Corbett DR, van de Plassche O, Gehrels WR, et al. Timing and magnitude of recent accelerated sea-level rise (North Carolina, United States). Geology. 2009;37(11):1035-8.

80. Kemp AC, Horton BP, Vane CH, Corbett DR, Bernhardt CE, Engelhart SE, et al. Sea-level change during the last 2500 years in New Jersey. USA Quat Sci Rev. 2013;81:90-104.

81. Leorri E, Horton BP, Cearreta A. Development of a foraminiferabased transfer function in the Basque marshes, N. Spain: implications for sea-level studies in the Bay of Biscay. Mar Geol. 2008;251(1-2):60-74.

82. Gehrels WR, Kirby JR, Prokoph A, Newnham RM, Achterberg EP, Evans H, et al. Onset of recent rapid sea-level rise in the western Atlantic Ocean. Quat Sci Rev. 2005;24(18-19):2083-100.

83. Gehrels WR, Marshall WA, Gehrels MJ, Larsen G, Kirby JR, Eiríksson J, et al. Rapid sea-level rise in the North Atlantic Ocean since the first half of the nineteenth century. The Holocene. 2006;16(7):949-65.

84. Gehrels WR, Hayward B, Newnham RM, Southall KE. A 20th century acceleration of sea-level rise in New Zealand. Geophys Res Lett. 2008;35(2):L02717.

85. Mörner N-A. Some problems in the reconstruction of mean sea level and its changes with time. Quat Int. 2010;221(1-2):3-8.

86. Engelhart SE, Peltier WR, Horton BP. Holocene relative sea-level changes and glacial isostatic adjustment of the U.S. Atlantic coast. Geology. 2011;39(8):751-4.

87. Mitrovica JX, Gomez N, Morrow E, Hay C, Latychev K, Tamisiea ME. On the robustness of predictions of sea level fingerprints. Geophys J Int. 2011;187(2):729-42.

88. Yin J, Schlesinger ME, Stouffer RJ. Model projections of rapid sea-level rise on the northeast coast of the United States. Nat Geosci. 2009;2(4):262-6.

89. Ezer T, Atkinson LP, Corlett WB, Blanco JL. Gulf Stream's induced sea level rise and variability along the U.S. mid-Atlantic coast. J Geophys Res Oceans. 2013;118(2):685-97.

90. Brown S, Nicholls RJ. Subsidence and human influences in mega deltas: the case of the Ganges-Brahmaputra-Meghna. Sci Tot Environ. 2015;527-528:362-74. Provides an excellent summary of different methods of measuring subsidence and how these vary through time and space.

91. Meckel TA, ten Brink US, Williams SJ. Current subsidence rates due to compaction of Holocene sediments in southern Louisiana. Geophys Res Lett. 2006;33(11)

92. Tosi L, Carbognin L, Teatini P, Strozzi T, Wegmüller U. Evidence of the present relative land stability of Venice, Italy, from land, sea, and space observations. Geophys Res Lett. 2002;29(12):3-1-3-4.

93. Morris JT, Sundareshwar PV, Nietch CT, Kjerfve B, Cahoon DR. Response of coastal wetlands to rising sea level. Ecology. 2002;83(10):2869-77.

94. Dixon TH, Amelung F, Ferretti A, Novali F, Rocca F, Dokka R, et al. Space geodesy: subsidence and flooding in New Orleans. Nature. 2006;441(7093):587-8. 
95. Teatini P, Tosi L, Strozzi T, Carbognin L, Cecconi G, Rosselli R, et al. Resolving land subsidence within the Venice Lagoon by persistent scatterer SAR interferometry. Phys Chem Earth Parts A/B/ C. $2012 ; 40-41: 72-9$.

96. Teatini P, Strozzi T, Tosi L, Wegmüller U, Werner C, Carbognin L. Assessing short- and long-time displacements in the Venice coastland by synthetic aperture radar interferometric point target analysis. J Geophys Res Earth Surf. 2007;112(F1).

97. Teatini P, Castelletto N, Ferronato M, Gambolati G, Janna C, Cairo E, et al. Geomechanical response to seasonal gas storage in depleted reservoirs: a case study in the Po River basin, Italy. J Geophys Res Earth Surf. 2011;116(F2).

98.• Higgins SA, Overeem I, Steckler MS, Syvitski JPM, Seeber L, Akhter SH. InSAR measurements of compaction and subsidence in the Ganges-Brahmaputra Delta, Bangladesh. J Geophys Res Earth Surf. 2014;119(8):1768-81. Key recent study that uses InSAR to constrain contemporary rates of subsidence in deltas.

99. Hanebuth TJJ, Kudrass HR, Linstädter J, Islam B, Zander AM. Rapid coastal subsidence in the central Ganges-Brahmaputra Delta (Bangladesh) since the 17th century deduced from submerged salt-producing kilns. Geology. 2013;41(9):987-90.

100. Marriner N, Flaux C, Morhange C, Kaniewski D. Nile Delta's sinking past: quantifiable links with Holocene compaction and climate-driven changes in sediment supply? Geology. 2012.

101. Teatini P, Tosi L, Strozzi T. Quantitative evidence that compaction of Holocene sediments drives the present land subsidence of the Po Delta, Italy. J Geophys Res Solid Earth. 2011;116(B8).
102. Erban LE, Gorelick S, Zebker HA. Groundwater extraction, land subsidence, and sea-level rise in the Mekong Delta. Vietnam Environ Res Lett. 2014;9(8):084010.

103. Shi X, Fang R, Wu J, Xu H, Sun Y, Yu J. Sustainable development and utilization of groundwater resources considering land subsidence in Suzhou. China Eng Geol. 2012;124:77-89.

104. Higgins S, Overeem I, Tanaka A, Syvitski JPM. Land subsidence at aquaculture facilities in the Yellow River delta, China. Geophys Res Lett. 2013;40(15):3898-902.

105. Osmanoğlu B, Dixon TH, Wdowinski S, Cabral-Cano E, Jiang Y. Mexico City subsidence observed with persistent scatterer InSAR. Int J Appl Earth Obs Geoinf. 2011;13(1):1-12.

106. Chaussard E, Amelung F, Abidin H, Hong S-H. Sinking cities in Indonesia: ALOS PALSAR detects rapid subsidence due to groundwater and gas extraction. Remote Sens Environ. 2013;128:150-61.

107. Hay CC, Morrow E, Kopp RE, Mitrovica JX. Probabilistic reanalysis of twentieth-century sea-level rise. Nature. 2015;517(7535): $481-4$.

108. Nerem RS, Chambers DP, Choe C, Mitchum GT. Estimating mean sea level change from the TOPEX and Jason altimeter missions. Mar Geod. 2010;33(sup1):435-46.

109. Mudd SM, Howell SM, Morris JT. Impact of dynamic feedbacks between sedimentation, sea-level rise, and biomass production on near-surface marsh stratigraphy and carbon accumulation. Estuar Coast Shelf Sci. 2009;82(3):377-89. 